\title{
RoMAN SOBOTKA
}

Uniwersytet Warszawski

\section{MIĘDZY MONARCHIĄ STANOWĄ A DEMOKRACJĄ SZLACHECKĄ. ZNACZENIE PRZYWILEJÓW NIESZAWSKICH W PERIODYZACJI DZIEJÓW POLSKI}

\section{WsTĘP}

Na początek chciałbym przytoczyć słowa Bolesława Ulanowskiego. „Wygaśnięcie na Kazimierzu W. dynastyi piastowskiej otwarło szlachcie polskiej drogę do stopniowego zajmowania w organizmie państwowym coraz to bardziej wpływowego stanowiska. Rządy Ludwika, a zwłaszcza bezkrólewie po jego śmierci były epoką, w której żywioł szlachecki doszedł do samowiedzy potęgi, którą przedstawiał, i celów, które mógł osiagnąć. Panowania Władysława Jagiełły i Władysława Warneńczyka sprzyjały dążnościom szlacheckim, a Kazimierz Jagiellończyk w pełnym rozwoju będącego już ruchu ani opanować nie mógł ani nawet osłabić. W długim tym, sto lat przeszło liczącym okresie, wykształcają się powoli wszystkie instytucyje naszego parlamentaryzmu: konfederacyje, oraz zjazdy ziemskie, dzielnicowe i walne, będące zawiązkiem późniejszych sejmików i sejmów koronnych; dochodzi do skutku ograniczenie władzy królewskiej i dobijająca się o udział w rządach szlachta w jak najszerszych rozmiarach urzeczywistnia swoje marzenia. $Z$ tych powodów okres ten między r. 1370 a 1505 można by w historyi prawa publicznego w Polsce nazwać „walką o konstytucyę". Walka ta była istotnie mozolną i zaciętą, odnawiającą się przy 
każdej sposobności i prowadzoną ze strony szlachty z dziwnie nieubłaganą konsekwencyą".

W tym fragmencie widać kilka cech charakterystycznych starej historiografii: jest to mianowicie śledzenie ex post linii rozwojowych i zwracanie szczególnej uwagi na te wydarzenia, które do niej przystają (np., od sprowadzenia Krzyżaków do rozbiorów i II wojny światowej; od braku zgody na podatki na sejmach XVI w. do niemocy państwowej w połowie XVIII w.). Między innymi na podstawie powyższego fragmentu współcześni badacze konstatują: „Gdy od połowy XV w. Europa Zachodnia zmierzała w stronę monarchii absolutnej, Polska kierowała się ku demokracji szlacheckiej"2. Trzeba by jednak w takim razie z Europy Zachodniej wyłączyć Anglię, Zjednoczone Prowincje, a także Konfederację szwajcarską.

Powyższe przemyślenia skłoniły mnie do podjęcia jednego z tematów często poruszanych w literaturze naukowej. Idzie mianowicie o kwestię znaczenia przywilejów nieszawskich dla rozwoju życia sejmikowego i tym samym - dla początków parlamentaryzmu polskiego.

\section{RoK 1454 I Jego ZnACZenie DlA histori Ustroju POLSKI}

Twórcy nauki historycznoprawnej (Oswald Balzer i Tadeusz Kutrzeba) ,wyróżniając w dziejach państwa polskiego pewne okresy historyczne, tworzyli tym samym modele ustrojowe"3. Periodyzacja jest

${ }^{1}$ B. Ulanowski, Trzy zabytki do historyi parlamentaryzmu $w$ Polsce $w$ XV wieku, Archiwum Komisji Prawniczej, T. I, s. 145.

2 J. BYliński, W. KaCzorowski, Ciag dalszy losów korektury prawa za panowania Zygmunta III Wazy, [w:] O prawie i jego dziejach księgi dwie. Studia ofiarowane Profesorowi Adamowi Lityńskiemu w czterdziestolecie pracy naukowej i siedemdziesięciolecie urodzin, red. M. MiкоŁAлczyк i in., I, Białystok 2010, s. 245. Tak też T. Maciejewski, Historia ustroju i prawa sqdowego Polski, Warszawa 1999, s. 35.

${ }^{3} \mathrm{~W}$. UruszczaK, Typologizowanie ustrojów politycznych $w$ polskiej nauce historyczno-prawnej $i$ historycznej XIX $i$ XX w., [w:] Przez tysiaclecia: państwoprawo-jednostka. Materiaty ogólnopolskiej konferencji historyków prawa, Ustroń 1720 września 2000 r., red.: A. LityńsKi, M. MikoŁAJCZYK, III, Katowice 2001, s. 48. 
ważna w rozważaniach historyczno-prawnych ${ }^{4}$. Ułatwia bowiem syntezę, pozwala ograniczyć przedstawianie określonej problematyki dzięki wskazaniu zasadniczych linii rozwojowych charakterystycznych dla danej epoki. To periodyzacje, poprawnie konstruowane, nadają rangę wydarzeniom. Poprzez nie wiedza o faktach trafia do świadomości powszechnej (jako wiedza o ich tzw. ,przełomowym znaczeniu”). Jak twierdzą niektórzy, „historia jest tym, co jesteś w stanie zapamiętać”.

Piewcą znaczenia przywilejów nieszawskich był Adolf Pawiński. Przywileje cerekwickie nazywał „Magna Charta” szlachty - przyrównując je w ten sposób do przywileju angielskiego króla Jana ${ }^{6}$. Uznał on, że przywileje nieszawskie wywołały ,głęboki przewrót w stosunkach publicznych"7. Specyfiką ich miało być oparcie się na jednostce podziału administracyjnego, jaką tworzyła ziemia i ogół szlachty. Dlatego widział w nich ,,pierwsze u nas karty konstytucyjne ziem oddzielnych”. Wedle słów warszawskiego historyka, po 1454 „sejmik staje się warownią życia praw i przywilejów szlachty"9. I jeszcze inne jego stwierdzenie: „Od połowy w. XV poza zjazdem walnym nie może nastapić wydanie nowego statutu ani zwołanie pospolitego ruszenia, każdy zaś zjazd walny musi być poprzedzony przez sejmiki"

Pierwotnie sejmiki były zasadniczo niezwiązane z sejmami, i tylko wyjątkowo te pierwsze poprzedzały te drugie. Tak było co najwyżej do r. $1454^{11}$. Siemieński zwraca uwagę na oryginalne brzmienie

${ }^{4}$ J. Matuszewski, Czy podręcznik powinien być stuszny czy raczej dobry? W zwiqzku z pracq Mariana Kallasa, Historia ustroju Polski, «CPH» 59.1/2007, s. 296.

${ }_{5}$ D.R. Kelley, Granice historii. Badanie przeszłości w XX wieku, Warszawa 2010, s. 271.

${ }^{6}$ A. PAwIŃSKI, Sejmiki ziemskie, początek ich i rozwój aż do ustalenia się udziału posłów ziemskich w ustawodawstwie sejmu walnego, Warszawa 1895, s. 70.

7 Tamże, s. 71.

8 Tamże, s. 72.

9 Tamże, s. 74.

${ }^{10}$ J. Siemieński, Ustrój Rzeczpospolitej Polskiej. Wykład syntetyczny, LwówWarszawa 1922, s. 12.

11 J. SiemieńsKi, Od sejmików do sejmu 1454-1505, [w:] Studia historyczne ku czci Stanisława Kutrzeby, I, Kraków 1938, s. 448. 
przepisów, zgodnie z którymi król zobowiązany był do zwołania, ale nie do uzyskania zgody sejmu w sprawach nowych konstytucji czy pociagnnięcia na wojnę szlachty ${ }^{12}$. A sejm poprzedzały sejmiki. Wedle Siemieńskiego szlachta chciała być tylko uprzedzana na sejmikach o tematyce obrad sejmu walnego ${ }^{13}$. Rok 1454 niewiele zmienił w zakresie uprawnień szlachty. Przywileje nieszawskie w drobnej mierze zaspokoiły potrzeby szlachty, ale nie rozwiązały problemów organizacji obrad szlachty czy zdobycia przewagi na sejmiku przez przypadkową większość (np. szlachty zamieszkałej najbliżej miejsca obrad) ${ }^{14}$. By uniknąć tych niedogodności wymyślono zasadę reprezentacji na sejmie walnym i stworzono Izbę Poselską (Siemieński wiąże to z konstytucją Nihil novi).

Witold Knoppek uznał, że „w przeciwieństwie do stanu rzeczy sprzed roku 1454 po wydaniu statutów na zjeździe walnym uchwalano tylko projekty ustaw podatkowych i powołanie pospolitego ruszenia, odsyłając stanowczą uchwałę do sejmików ${ }^{15}$ ". Warto zauważyć, że autor ten nazywał zjazdy prowincjonalne sejmikami.

Postanowienie zajmujące się sejmikami z przywilejów cerekwickiego i nieszawskiego były przedmiotem licznych analiz. Stan badań do połowy XX w. podsumował Stanisław Roman poświęcając im cały rozdział swej książki o przywilejach nieszawskich. Sam autor uznał, że ,już przed 1454 sejmiki z udziałem szlachty odgrywały rolę zarówno w ustawodawstwie, jak i w powoływaniu pospolitego ruszenia"16. Do tych wniosków doszedł na podstawie analizy tekstów przywilejów i literatury im poświęconej. Nie sprawdzał, jak było w praktyce życia publicznego. Poza tym przyjął, że sejmiki i sejmy powstały z wieców, które posiadały stanowcze kompetencje w sprawach ustawodawstwa i zwoływania pospolitego ruszenia. Wojciech Hejnosz, w recenzji

12 Tamże, s. 455.

13 Tamże, s. 455.

14 Tamże, s. 456.

15 W. KNoppeK, Zmiany $w$ układzie sit politycznych $w$ Polsce $w$ drugiej połowie $X V$ w. i ich zwiazek z geneza dwuizbowego sejmu, «CPH» 7.2/1955, s. 69.

16 S. Roman, Przywileje nieszawskie, Wrocław 1957, s. 128. 
książki Romana, nie zgodził się z tym stanowiskiem, uznając znaczenie przywilejów nieszawskich dla walki szlachty z możnowładztwem ${ }^{17}$.

Zasadniczą rolę przywilejów nieszawskich dla ustroju państwowego przyjmowali nie tylko historycy prawa. Marian Biskup uznał, że szlachta i sejmiki „od czasów przywilejów nieszawskich 1454 r. stawały się decydującym faktorem w sprawach ogólnopaństwowych" ${ }^{18}$. Powszechność cezury roku 1454 stwierdzał też Henryk Litwin ${ }^{19}$.

Po wojnie Zygmunt Wojciechowski napisał w swojej syntezie: „Wprawdzie statuty nie mówią o wyrażaniu przez sejmiki zgody na nowe konstytucje i na powołanie pospolitego ruszenia, ale tak niewątpliwie ten ustęp należy rozumieć" 20 .

W nowych, powojennych warunkach nacisku ideologicznego na naukę cezura roku 1454 została przyjęta, według ideologii marksistowskiej, jako początek nowej formy państwa. Obok Zdzisława Kaczmarczyka ${ }^{21}$ promotorem idei znaczenia roku 1454 dla periodyzacji był Juliusz Bardach. Przywileje nieszawskie były wedle tego uczonego przełomowe dla ustroju Polski i przesądzały o jej późniejszej odmienności ustrojowej. Odmienności, którą profesor Bardach oceniał pozytywnie. Jego zdaniem, gdy w Europie wzrastał absolutyzm, „Polska z obieralnym królem o władzy silnie ograniczonej przez sejm i sejmiki ziemskie wykształciła formę rządów, którą dla drugiej połowy XV i XVI wieku określamy, jako „demokrację szlachecką". Początek tej nowej formy widzimy w działalności sejmików, które od statutów nieszawskich posiadały ustawowo oznaczone $\mathrm{i}$ istotne kompetencje prawodawcze"22. Juliusz Bardach bronił naukowo-

17 W. Hesnosz, «CPH » 10.2/1958, s. 434-440.

18 M. Biskup, Trzynastoletnia wojna z Zakonem Krzyżackim 1454-1466, Warszawa 1967, s. 733.

${ }^{19}$ H. Litwin, Magnateria polska 1454-1648. Ksztaltowanie sie stanu, «PHist.» $74.3 / 1983$, s. 452.

20 Z. Wojciechowski Państwo polskie w wiekach średnich², Poznań 1948, s. 287.

${ }^{21}$ Z. KACZMARCZYK, Typ i forma państwa polskiego $w$ okresie demokracji szlacheckiej, [w:] Odrodzenie w Polsce, I: Historia, Warszawa 1955, s. 482, 499.

22 J. Bardach, O genezie sejmu polskiego, [w:] Pamiętnik VIII Powszechnego Zjazdu Historyków Polskich w Krakowie 14-17 września 1958 r., Referaty, II, Warszawa 1958, s. 521. 
ści określenia „demokracja szlachecka”23. To znaczenie, jakie przykładał on do r. $1454^{24}$ i terminu demokracja szlachecka, która wtedy miała się narodzić, wywarło ogromny wpływ na periodyzację syntez państwa i prawa polskiego, które powstały pod jego redakcją.

Według Bardacha praktyka uzyskiwania zgody sejmików na podatek ukształtowała się po 1454. Wtedy zgoda sejmu nie była wiążąca, ale wstępna, która dla swej ważności wymagała zgody sejmików lub sejmów prowincjonalnych ${ }^{25}$.

Cechę charakterystyczną sejmu w XV w. Juliusz Bardach widział w alternatywności zgromadzeń, tj.: ogólnopaństwowego sejmu walnego, sejmów prowincjonalnych (wielkopolskiego i małopolskiego, zwanych generalnymi) i sejmików ziemskich. Zamienne funkcjonowanie tych zgromadzeń, wyposażonych w funkcję prawodawczą, było możliwe w warunkach utrzymywania się odrębności lokalnych i stanowiło polską specyfikę. Do różnic prowincjonalnych zaliczał większą rolę średniej szlachty w Wielkopolsce, a możnowładztwa w Małopolsce. Wspieranie wspólnot regionalnych leżało w interesie króla, który w ten sposób mógł wygrywać poparcie jednych przeciw innym. Tak więc można zauważyć pewną tendencję osłabienia władzy monarszej i jednocześnie wzrostu znaczenia możnowładztwa i sejmu walnego w pierwszej połowie XV w., a zarazem umocnienia władzy króla wraz ze wzrostem roli sejmików w drugiej połowie XV w. Jak zauważał Profesor, ta tendencja z czasów Kazimierza Jagiellończyka występowała też współcześnie we Francji, której królowie przedkładali stany prowincjonalne nad generalnymi ${ }^{26}$.

Dostrzegając odrębności lokalne Juliusz Bardach nie zwrócił jednak uwagi na różnice $\mathrm{w}$ tekstach przywilejów nieszawskich wydawanych dla poszczególnych ziem - choć znał pracę Romana o przywilejach

${ }^{23}$ Tamże, s. 521 i n.

${ }^{24}$ Pisał, że nie dość jest podkreślać wage przywilejów nieszawskich dla rozwoju parlamentaryzmu, J. BARDACH, O genezie sejmu..., s. 534.

25 J. Bardach, Historia Sejmu Polskiego, I, pod red. J. Michalskiego, Warszawa 1984, s. 37.

${ }^{26}$ J. BARDACH, O genezie sejmu..., s. 529 i n. 
nieszawskich. Omawiając dokładnie dwa artykuły przywileju cerekwickiego (o zniesieniu nowych ceł oraz o uprzedniej zgodzie wspólnoty ziemskiej na zwołanie pospolitego ruszenia i stanowienie nowych praw) odnosił je do całego państwa, choć Roman ustalił, że przywilej w Cerekwicy wydano dla Wielkopolski, został on zastapiony później przez nową wersję przywileju nieszawskiego ${ }^{27}$, w którym wspomniany artykuł mówi wyraźnie o zgodzie sejmiku w Środzie ${ }^{28}$. Później zauważał różnice lokalne, lecz zasadniczo podtrzymywał swą ocenę znaczenia rozwiązań z $1454 \mathrm{r} .{ }^{29}$ Między innymi nadawał trwałe znaczenie artykułowi z przywileju korczyńskiego dla Małopolski z $1456 \mathrm{r}$. o zgodzie sejmu prowincjonalnego na zwołanie pospolitego ruszenia z tej prowincji, choć sam podkreślał, że miał on obowiązywać w czasie wojny z Zakonem.

W rozwoju sejmu za Kazimierza Jagiellończyka i udziale wspólnoty szlacheckiej w sprawowaniu władzy Juliusz Bardach widział trwałą tendencję rozwojową ${ }^{30}$, która doprowadziła do rozkwitu parlamentaryzmu w XVI stuleciu. Nie zgadzał się tym samym z historykami, którzy w rządach młodszego syna Jagiełły widzieli tendencje protoabsolutystyczne $^{31}$. Swoje stanowisko podtrzymywał w późniejszych pracach, gdzie też dokładnie je uzasadnit ${ }^{32}$.

Wedle Antoniego Mączaka monarcha wskutek przywilejów nieszawskich utracił prawo nakładania podatków bez zgody sejmików ${ }^{33}$. Zdaniem tego uczonego przywileje owe „Zwiększyły znakomicie kom-

27 S. Roman, Przywileje nieszawskie..., s. 191.

${ }_{28}$ convencione communi terrestri in Srzoda.

29 J. BARDACH, Historia sejmu polskiego..., s. 32-35.

30 J. BARDACH, O genezie sejmu..., s. 539.

${ }^{31}$ K. GórsKI, Rządy wewnętrzne Kazimierza Jagiellończyka w Koronie, [w:] M. BISKUP, K. GóRSKI, Kazimierz Jagiellończyk. Zbiór studiów o Polsce drugiej połowy XV wieku, Warszawa 1987, s. 122 i n.

32 J. BARDACH, Historia sejmu polskiego..., s. 58 i n.; Tenze, O stawaniu się sejmu polskiego we współczesnej historiografii [w:] Parlamentaryzm w Polsce we wspótczesnej historiografii, red. J. BARDACH, Warszawa 1995, s. 33 i n.

33 A. MączaK, Rzqdzqcy i rzqdzeni. Władza i spoleczeństwo w Europie wczesnonowożytnej, Warszawa 1986, s. 83. 
petencje sejmików ziemskich: one to według przywileju udzielonego Wielkopolanom, miały odtąd decydować o proponowanych przez króla nowych prawach i zwołaniu pospolitego ruszenia"34. Tadeusz Szulc się z nim nie zgadza i podkreśla, że już od 1374 królowie nie mogą nakładać nadzwyczajnych podatków ${ }^{35}$.

Periodyzacja Juliusza Bardacha, wprowadzona w wielokrotnie wznawianym podręczniku dla studentów prawa ${ }^{36}$, ,stanowi sui generis kanon w opisie dziejów ustrojowych i prawnych dawnej Polski" ${ }^{37}$. Opierają się na niej współcześni autorzy podręczników historii państwa i prawa polskiego ${ }^{38}$.

Marian Kallas, choć nie przyjął cezury 1454, to stwierdził, że wydatne wzmocnienie pozycji sejmików ziemskich nastąpiło wskutek wydania przywilejów nieszawskich ${ }^{39}$. Jacek Matuszewski zaliczył przywileje nieszawskie do aktów „kształtujących zasady ustroju politycznego i społecznego państwa" ${ }^{40}$. Współcześnie wagę roku 1454 podkreśla Stanisław Salmonowicz, choć nie czyni tej daty cezurą pierwszoplanową swej periodyzacji (Królestwo Polskie 1320-1569; Rzeczpospolita polsko-litewska 1569-1795) ${ }^{41}$.

Ostatnio Wacław Uruszczak skrytykował marksistowskie podstawy periodyzacji Polski i zanegował samo funkcjonowanie demokracji szlacheckiej ${ }^{42}$. W swoim podręczniku przyjął periodyzację opartą

34 Tamże, s. 135.

${ }^{35}$ T. SzuLc, Uchwaty podatkowe ze szlacheckich dóbr ziemskich za pierwszych Jagiellonów (1386-1501), Łódź 1992, s. 37, przyp. 8.

36 J. Bardach, B. LeŚnOdorski, M. Pietrzak, Historia ustroju i prawa polskiego ${ }^{6}$, Warszawa 2009.

37 W. UruszczaK, Typologizowanie ustrojów politycznych..., s. 51.

38 T. Maciejewski, op. cit., s. V.

39 M. Kallas, Historia ustroju Polski, Warszawa 2005, s. 137.

40 J. Matuszewski, Czy podręcznik powinien być..., s. 301.

${ }^{41}$ S. Salmonowicz, Cezura roku 1569: z problematyki periodyzacji ustroju dawnej Rzeczypospolitej, [w:] O prawie i jego dziejach księgi dwie, s. 361, przyp. 9, 362, 364.

42 W. Uruszczak, Formy dawnego państwa polskiego. Uwagi dyskusyjne, «CPH» 45.1-2/1993, s. 414. 
na okresach panowania dynastii i czasów wolnej elekcji ${ }^{43}$. Na koniec można zauważyć, że nowe czasy uzmysławiają badaczom nowe potrzeby periodyzacyjne i terminologiczne.

Połowa XV w. jako granica periodyzacyjna przyjmowana jest także $\mathrm{z}$ innych, pozaustrojowych, względów. Wszak w tym czasie nastapiło wynalezienie druku, co zrewolucjonizowało komunikację międzyludzką. Zwiększyły się możliwości propagowania różnych idei, w tym przekonań politycznych. Od 1454 zwiększa się zdecydowanie liczba zachowanych dokumentów, co znajduje odzwierciedlenie w księgach Metryki Koronnej. Dlatego w XIX w. często przyjmowano połowę XV w. jako datę graniczną wydawnictw źródłowych, jak Kodeks Dyplomatyczny Małopolski czy Wielkopolski. W 1466 r. do Królestwa Polskiego przyłączono ostatecznie ujście Wisły, dzięki czemu uzyskano dogodne warunki dla zbytu zboża, to zaś przyspieszyło rozwój folwarku szlacheckiego ${ }^{44}$. Rozwój folwarku umocnił ekonomicznie tzw. średnią szlachtę, która wzmocniwszy się, sformułowała własny program polityczny - ruch egzekucyjny.

Trzeba jednak zauważyć, że druk dotarł do Polski z dużym opóźnieniem. Najstarszy druk praw polskich (tzw. Syntagmata) drukowano w Lipsku w 1487 r. ${ }^{45}$ Najstarszy druk na ziemiach polskich to kalendarz astronomiczny pochodzący z impresorni wędrownego drukarza Kaspra Straubego z 1473 r. Wśród najstarszych druków przeważała literatura kościelno-liturgiczna ${ }^{46}$. Data natomiast końcowa wydawnictw dokumentowych jest przypadkowa. Rozwój folwarku nastapił przed

${ }^{43}$ W. Uruszczak, Historia państwa i prawa polskiego, I: (966-1795), Warszawa 2010.

${ }^{44}$ M. Biskup, Elementy gospodarcze podtoża zjednoczenia Pomorza Wschodniego z Polska w połowie XV w., [w]: M. Biskup, K. Górski..., s. 18-81. R. Grodecki, Poczatki gospodarki folwarcznej w Polsce, [w:] Studia z dziejów kultury, red. H. BARYCZ, J. Hulewicz, Warszawa 1949, s. 64 i n.

${ }^{45}$ Polskie statuty ziemskie $w$ redakcji najstarszych druków (Syntagmata), oprac. L. ŁysiaK, S. Roman, Wrocław-Kraków 1958 s. 20 i n.

46 T. Ulewicz, Wśród impresorów krakowskich doby renesansu, Kraków 1977, s. $17 \mathrm{in}$. 
1466 r., a eksport zboża, zintensyfikowany po przyłączeniu Pomorza, przybrał znaczące rozmiary dopiero $\mathrm{W}$ XVI w. ${ }^{47}$

Kiedyś przyjmowano, że schyłek średniowiecza nastapił z upadkiem Konstantynopola ${ }^{48}$, gdyż liczna emigracja uczonych greckich przeniosła na Zachód, a najpierw do Włoch coraz doskonalszą znajomość antycznej literatury greckiej. Jednak exodus uczonych greckich rozpoczął się już na początku XV w. i trwał bez przerwy, a przybierał na sile w czasie soboru w Ferrarze i Florencji (1438 r.) i katastrofy roku $1453^{49}$.

Nie wszyscy badacze dziejów przyjmowali dla periodyzacji cezurę roku 1454. Zdaniem Adama Vetulaniego - powołującego się na Stanisława Romana ${ }^{50}$ - ,przywileje nieszawskie dla Wielkopolski ze swym przepisem o kompetencji sejmików nie wprowadzały żadnej istotnej nowości do ustroju państwa polskiego" "51. Profesor Vetulani uważał tak, przyjmując, że wzmiankowane przywileje przeniosły na sejmiki uprawnienia podatkowe, co - jak staram się wykazać w niniejszym artykule - w rzeczywistości nie nastąpiło. Co więcej, Vetulani nie przykładał też większego znaczenia do powstanie dwuizbowego Sejmu, uznając dopiero rolę artykułów henrykowskich ${ }^{52}$.

$\mathrm{Z}$ innego punktu widzenia spojrzał na sprawę szwajcarski uczony Gottfried Schramm. Zauważył on, że w wyniku równocześnie przebiegających procesów, zakończonych zasadniczo ok. r. 1500, warstwy uprzywilejowane Polski, Czech i Weggier doprowadziły do wykształcenia 3 typów kultury politycznej ${ }^{53}$.

47 J. Rutkowski, Historia gospodarcza Polski³ , I, Poznań 1947, s. 120.

${ }^{48}$ H.-D. HeImann, Wprowadzenie do historii średniowiecznej, thum. S. KwIATKOWSKI, Toruń 1999, s. 32.

49 P.O. Kristeller, Renaissance thought and its sources, New York 1979, s. 143.

${ }^{50}$ S. Roman, Przywileje nieszawskie..., s. 98 i n.

51 A. Vetulani, Nowe spojrzenie na dzieje państwa i prawa dawnej Rzeczypospolitej, «CPH»10.2/1958, s. 330.

52 Tamże, s. 332 i n.

${ }^{53}$ G. Schramm, Polska - Czechy - Wegry. Wspólne cechy kultury politycznej trzech krajów w późnym średniowieczu i wczesnym okresie nowożytnym, [w:] Polska w dziejach Europy środkowej. Studia, Poznań 2010, s. 19. 


\section{ARTYKUŁ o SEJMIKACH W PRZYWILEJACH NIESZAWSKICH}

Choć w literaturze ustaliło się nazywanie aktów prawnych wydanych w 1454 przywilejami, to trzeba pamiętać, że większość ich postanowień ma charakter statutowy ${ }^{54}$. W niniejszym tekście będę posługiwał się nazwą przywilejów, także dlatego, że będę rozpatrywał głównie przepisy dotyczące prawa politycznego, a więc nie statutowego.

Twierdzenia literatury historycznej o przełomowym znaczeniu wydarzeń roku 1454 dla kształtowania ustroju Polski wywodzą się z przywilejów, które wystawił król pod koniec owego roku. Warto przypomnieć ustalenia Stanisława Romana, który przywilejom nieszawskim poświęcił monografię. Omawiane przywileje istnieją w wielu redakcjach. Najstarsza jest wersja dla szlachty wielkopolskiej, wydana 15 września w Cerekwicy. Dla nas interesujące są dwa artykuły ${ }^{55}$ zawarte w tym przywileju. W art. 17 król znosił wszystkie cła nałożone ostatnio poza sejmami (extra generales conventiones instituta) ${ }^{56}$. Art. 18 przytoczę tu w całości, gdyż jest kluczowy dla niniejszych rozważań: „Aby zaś w przyszłości państwo było zdrowiej rządzone, chcemy i niniejszym stanowimy, aby żadne nowe instytucje nie były ustanawiane w wyniku prywatnych narad i aby żadna wyprawa wojenna nie była postanawiana w jakikolwiek sposób bez zjazdu wspólnoty ziemskiej, lecz by wszystkie rzeczy na nowo wymyślone były, przed ustanowieniem i uchwaleniem, przedyskutowane na zjazdach wspólnot ziemskich" [thum. RS ${ }^{57}$.

${ }^{54}$ S. Roman, Przywileje nieszawskie..., s. 10

55 Oryginalne wydania dokumentów nie zawierały podziału na paragrafy. Tym bardziej nie były one numerowane. Podziały i numeracja pochodzą od wydawców, jednak zostały przyjęte się w literaturze, która posługuje się odniesieniami do numerów artykułów.

56 J.W. BandtKie, Ius Polonicum, Varsoviae 1831, s. 267: Cassamus insuper omnia et singula thelonea, noviter per nos extra generales conventiones instituta, et ad petita nostrorum quorumcunque subditorum facta et confirmata, quae praesenti statuto volumus fieri revocata, nec aliquid perpetui roboris efficaciter obtinere.

57 Tamże, s. 267: Ut igitur respublica in posterum sanius dirigatur, volumus et praesentibus statutimus, ne aliquae novae institutiones privatis consiliis statuantur, 
Prawdopodobnie na wieść o przywileju dla Wielkopolan, szlachta małopolska spisała własne postulaty, których spełnienia domagano się od króla. Żądania te nazywane są petytami opockimi ${ }^{58}$. Król w odpowiedzi wydał 11 XI w Nieszawie przywilej tylko dla Małopolski ${ }^{59}$. W tym samym miejscu król wydał ponownie przywileje dla Wielkopolski, kasując przywilej cerekwicki.

Przywilej cerekwicki był dla całej Wielkopolski ${ }^{60}$. Świadczy o tym pięć artykułów przywileju poświęconych tylko Kujawom. W przywileju nieszawskim dla Wielkopolski brak owych artykułów. Nie ma też artykułów tylko dla Kujaw. Możliwe, że były one w odpisie dla Kujaw, który nie zachował się do późniejszych czasów. Prawdopodobnie przywileje cerekwickie/nieszawskie nie zostały nadane szlachcie dobrzyńskiej, gdyż przywileje o niej nie wspominają i w czasie wydawania przywilejów była ona nieobecna w miejscach ich wydawania ${ }^{61}$. Przywilej nieszawski w redakcji wielkopolskiej został wydany także dla ziemi sieradzkiej ${ }^{62}$. Odpowiednikiem art. 17 i 18 z redakcji cerekwickiej jest art. 33: "Także przyrzekamy, że żadnych nowych konstytucji nie ustanowimy, ani nie polecimy ziemianom na wojnę ruszyć bez zjazdu wspólnoty ziemskiej odbytego w Środzie" (Item pollicemur, quod nullas novas constitutiones faciemus, neque terrigenas ad bellum moveri mandabimus absque convencione communi terrestri in Srzoda

neque expeditio aliqua, absque communi terrestri conventione, in posterum suscitetur quovismodo, sed omnes res de novo inveniendae in conventionibus, communitatibus terrestribus prius practicatae, statuantur et laudentur.

58 S. Roman, Przywileje nieszawskie..., s. 61.

59 Tamże, s. 24 i n.

${ }^{60}$ J. WiesioŁowsKi, Najstarszy tekst przywileju nieszawskiego dla Wielkopolski, «CPH»18.1/1966, s. 84.

${ }^{61}$ H. Ruciński, Poczatki i rozwój szlacheckiej reprezentacji stanowej na Kujawach od końca XIV do poczqtków XVI wieku. «Bydgoskie Towarzystwo Naukowe Wydział Nauk Humanistycznych Seria C Nr 4, Prace Komisji Historycznej» 3/1966, s. 33.

${ }^{62}$ M. BobrzyŃski, O ustawodawstwie nieszawskiem Kazimierza Jagiellończyka, Kraków 1873, s. 25 i n. 
[singulis terris $\left.{ }^{63}\right]$ instituenda $\left.^{64}\right)$. Wersja sieradzka jako miejsce sejmiku wskazuje Sieradz ${ }^{65}$. Ta redakcja stała się później podstawą ogólnopolskiej wersji, którą Jan Olbracht zatwierdził w 1496 roku. Przywilej powszechny mówił o zwoływaniu sejmiku w każdej ziemi.

Następnie w konstytucjach z 1496 wymienione są (w art. 66 ${ }^{66}$ ) miejsca, w których mają odbywać się sejmiki przed pospolitym ruszeniem w celach konsultacyjnych (ad consultandum).

Petyta opockie i przywilej nieszawski dla Małopolski nie zawierają artykułu o sejmikach i pospolitym ruszeniu. Jednak podobne postanowienie można znaleźć $\mathrm{w}$ jednym $\mathrm{z}$ dokumentów pozostałych po sejmie prowincjonalnym w Nowym Mieście Korczynie z października 1456 r. Dokumenty wydał J.W. Bandtkie w Ius polonicum ${ }^{67}$. W omawianym dokumencie, zatytułowanym przez wydawcę Articuli ex conventione znalazł się zapis: Insuper expeditionem generalem versus terras Prussiae movere non debemus, nisi prius habita conventione desuper terrarum Cracoviensis, Sandomiriensis, Russiae, et Podoliae ${ }^{68}$. Jak widać, zobowiązanie królewskie dotyczyło tylko wypraw na Prusy i nie ma tu mowy nic o stanowieniu nowego prawa. Przed pospolitym ruszeniem miał odbyć się zjazd ziem małopolskich, więc chodzi nie o sejmiki ziemskie, lecz o sejm prowincjonalny - taki sam, na którym dokument sporządzono. Poza tym z treści tego dokumentu wynika, że mógł on mieć charakter petytów. Król obiecywał w nim, że zajmie się postulatami po powrocie z Litwy, na którą właśnie się udawał ${ }^{69}$. Nie ma więc pewności co do obowiązywania postanowień tego dokumen-

${ }^{63}$ Wersja z 1496: Volumina Constitutionum, do druku przygotowali S. GrodzISKI, I. Dwornicka, W. Uruszczak, T. 1: 1493-1549, Vol. 1: 1493-1526, Warszawa 1996, s. 66.

${ }^{64}$ Archiwum Komisji Prawniczej, V, Kraków 1897, s. 68.

65 in Siradia. M. Bobrzý́ski, O ustawodawstwie nieszawskiem..., s. $87 \S 31$.

66 Volumina Constitutionum, s. 77.

67 J.W. BANDTKIE, op. cit., s. 296-303.

68 Tamże, s. 299.

69 Zob. S. Roman, Przywileje nieszawskie..., s. 119. 
tu. W wydanym tamże przywileju dla Małopolski ${ }^{70}$ brak postanowienia o pospolitym ruszeniu.

8 XI 1488 na sejmie walnym w Piotrkowie nastapiło zatwierdzenie przywileju dla Wielkopolski. Zawiera mało postanowień i głównie z zakresu prawa sądowego, nie ma nic o sejmikach czy pospolitym ruszeniu ${ }^{71}$.

Już przed 1454 król zwoływał pospolite ruszenie za zgodą szlachty zgromadzonej bądź w jednym miejscu jednocześnie, bądź w kilku. Rozważane postanowienie znalazło się tylko w wersji wielkopolskiej przywileju nieszawskiego. Nie zmieniło ono praktyki, gdyż po 1454 o pospolitym ruszeniu decydowano raczej na sejmie walnym, lub na sejmach prowincjonalnych. Jednak art. 33 odgrywał chyba ważną rolę w życiu politycznym. Wskazuje na to walka o zatwierdzenie przywilejów po śmierci Kazimierza Jagiellończyka. W 1493 r. król potwierdził ogólnie przywileje nieszawskie ${ }^{72}$, a w 1496 r. ostatecznie zatwierdził je w redakcji wielkopolskiej ( $\mathrm{z}$ art. o sejmikach) jako tekst ogólnopolski. Możliwe, że to dwukrotne zatwierdzenie przywilejów nieszawskich było spowodowane wydaniem Syntagmatów (1487 i 1488 r.), w których wydrukowano petyta opockie, jako tekst ogólnopolski.

\section{Pospolite RUSZENIE, PODATKI NA WOJSKA NAJEMNE - PRAKTYKA}

Przedmiotem analizy będzie teraz działalność zgromadzeń stanowych związanych z finansowaniem działań wojennych. W związku z prowadzonymi wojnami kwestie podatków i pospolitego ruszenia stanowiły podstawowy zrąb działalności zjazdów stanowych. Ustawodawstwo schodzi na drugi plan, gdyż było stosunkowo rzadkie.

Po przedstawieniu poglądów literatury przedmiotowej na temat jednego z przywilejów wydanych w Nieszawie, chciałbym pokazać, jak w praktyce wyglądało podejmowanie uchwał o pospolitym ruszeniu lub zastępujących je podatkach. Warto przypomnieć, że w 1374 r. wprowa-

\footnotetext{
70 J.W. BANDTKIE, op. cit., s. 300 i n.

${ }^{71}$ Tamże, s. $321 \mathrm{i} \mathrm{n.}$

72 Volumina Constitutionum, s. 54 art. 21.
} 
dzono stały podatek „królestwo” w wysokości 2 groszy z osiadłego łanu dóbr chłopskich w majątkach szlacheckich. Po tym roku w ciagu następnych 73 lat tylko dwa razy uchwalono nadzwyczajne podatki: w 1404 r. na wykup ziemi dobrzyńskiej z rąk Krzyżaków i w 1440 r. na wyprawę węgierską Władysława III Jagiellończyka.

Za panowania Kazimierza Jagiellończyka po raz pierwszy uchwalono podatki na sejmie pokoronacyjnym w Piotrkowie w 1447 r. Nałożono podatek na wykupienie królewszczyzn z rąk zastawników w wysokości wiardunku (12 groszy) z łanu. W owym wiardunku wliczono „królestwo”, więc nadzwyczajny podatek wynosił 10 groszy ${ }^{73}$.

Kolejna informacja o podatkach nadzwyczajnych pochodzi z $1451 \mathrm{r}$. W Nowym Mieście Korczynie ${ }^{74}$ uchwalono 6 gr z łanu. Udział w zjeździe szlachty krakowskiej, sandomierskiej, lubelskiej jednoznacznie wskazuje, iż był to sejm generalny ${ }^{75}$.

Wzrost liczby wiadomości o podatkach wiąże się z rozpoczęciem wojny trzynastoletniej. Ogólną informację o podatku w 1454 roku podał Długosz, zaznaczając, że uchwalony podatek wiardunkowy nie przyniósł spodziewanych efektów ${ }^{76}$. Ogólna informacja o podatku nałożonym w marcu tegoż roku zachowała się w najstarszej zachowanej księdze Metryki Koronnej. Są tam odpisy dwóch dokumentów z marca 1454 r., w których mowa o sześciogroszowym podatku na obronę przeciw Tatarom. Nie wiadomo, gdzie podjęto decyzję o podatku ani na jakim obszarze miała obowiązywać 77 .

Obfitujący w uchwały podatkowe był rok 1455. Najpierw w styczniu sejm obozowy pod Łaszynem zakończył się uchwałami podatko-

73 T. SzULC, op. cit, s. 28 i n.

${ }^{74}$ Dalej to miasto będę nazywał Korczynem, gdyż w niniejszym artykule nie występuje inny Korczyn. Poza tym uchwały tam podejmowane i odbywane zjazdy nazywano korczyńskimi.

75 T. SzuLc, op. cit, s. 31-32.

76 J. Deugosz, 'Annales seu Cronicae incliti Regni Poloniae, Liber duodecimus' 1445-1461, Cracoviae 2003, s. 238; Tenże, Roczniki czyli Kroniki sławnego Królestwa Polskiego, Księga 12 1445-1461, Warszawa 2004, s. 268.

77 Najstarsza zachowana księga Metryki Koronnej nr 10 do 1455 r., wyd. A. MrsŁowsKi, W. GraniczNY, Warszawa 1914, nr 217, s. 193 i n.; nr 220, s. 199-200. 
wymi $^{78}$. Następnie w maju w Piotrkowie uchwalono wiardunek zamiast pospolitego ruszenia. Informatorem o tym zdarzeniu jest Długosz, który napisał: „pro solvendis fertonibus particulares convenciones in singulis terris decrete et altera convencio generalis ... in Pyotrkow instituta”... ${ }^{79}$. Można ten fragment przetłumaczyć: „dla zebrania podatków zwołano sejmiki”. Formuła ta nie przesądza o przyzwoleniu sejmiku na podatek, gdyż na sejmikach przecież wybierano poborców podatkowych. Dalej kronikarz napisał: „W Wielkopolsce, ponieważ dawało jej się we znaki bliskie, niemal wewnętrzne zło, za powszechną zgodą postanowiono płacić wiardunki i w końcu zaczęto je zbierać. A w ziemi krakowskiej wysuwano wiele sprzeciwów w stosunku do opłaty i nie można było nakłonić szlachty do płacenia wiardunków, chyba po przyjęciu warunku, by dzierżący na jakiejkolwiek zasadzie dobra królewskie, płacili połowę wszystkich dochodów. Z powodu tego warunku można się było raczej spodziewać wiardunków z ziem krakowskich [rozstrzelenie RS], niż je mieć. Bo dzierżawcy dóbr królewskich twierdzili, że absolutnie się nie zgodzą na ten warunek,

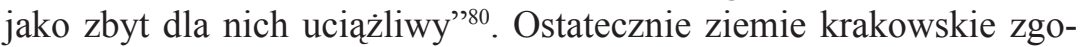
dziły się na wypłatę wiardunku na powtórnym zjeździe ${ }^{81} \mathrm{w}$ Piotrkowie, zapowiedzianym jeszcze w maju, a odbytym pod koniec czerwca.

W przytoczonym wyżej tekście kronikarza zwraca uwagę określenie ,ziemie krakowskie” czyli użycie nazwy w liczbie mnogiej. W ten sposób określał Długosz całą Małopolskę, czasem z Rusią. To oraz inne jeszcze określenie „Wielkopolska”, użyte na początku cytatu, wskazuje na podjęcie decyzji na sejmach prowincjonalnych. Tę tezę dodatkowo potwierdza dokument z 1455 r., w którym król Kazimierz Jagiellończyk dziękował szlachcie wielkopolskiej za zgodę na podatek w wys. 12 groszy z łana i jednocześnie gwarantował wolności podatkowe na przyszłość. Wymieniono w nim razem możnych i szlachtę

\footnotetext{
78 T. SzuLC, op. cit, s. 37 i n.

79 J. DŁugosz, 'Annales', 1445-1461..., s. 231.

80 J. DŁugosz, Roczniki, 1445-1461..., s. 262.

81 J. DŁugosz, 'Annales', 1445-1461..., s. 234.
} 
ziem Wielkopolski, sieradzkiej, łęczyckiej i kujawskiej². Jeśli więc wystawiono jeden dokument, można przypuszczać, że szlachta szeroko rozumianej Wielkopolski wyraziła zgodę jednocześnie ${ }^{83}$.

Jeszcze w listopadzie 1455 r. odbył się zjazd obozowy w Grudziądzu. Wobec sprzeciwu stałych doradców króla na nowe podatki, wybrano ${ }^{84}$ spośród szlachty nowych radców (iuniores), którzy zgodzili się na podatek (wiardunek z łanów szlacheckich, dwa wiardunki z łanów królewskich i duchownych, połowa dochodów od kleru). Uchwały te uchylono na zjeździe w Piotrkowie w następnym roku, choć prawdopodobnie częściowo zostały one zrealizowane ${ }^{85}$.

W styczniu 1456 r. w Piotrkowie postanowiono nowe podatki w miejsce uchylonych uchwał grudziądzkich, jednocześnie zdecydowano zwołać pospolite ruszenie ${ }^{86}$. We wrześniu tegoż roku, znowu w Piotrkowie dla opłacenia zaciężnych i wykupienia zamku malborskiego z rąk Ulryka Czerwonki uchwalono ze wszystkich dóbr (królewskich, szlacheckich i duchownych), urzędów i godności połowę wszystkich czynszów; na miasta i miasteczka nałożono po 2 grosze od grzywny dóbr ruchomych i nieruchomych; chłopów obciążono groszem od osoby bez względu na płeć; szlachta nie posiadająca kmieci miała

${ }^{82}$ Dokumenty kujawskie i mazowieckie przeważnie z XIII w., zebrał i wyd. B. UlANowsKI, [w:] Archiwum Komisji Historycznej AU, T. IV, Kraków 1888, nr 100. Też w Volumina legum, T. I Petersburg 1859, s. 85.

${ }^{83}$ Dokument wystawiono 31 października. Jako miejsce wystawienia podano Chojnice, jednak w tym czasie król z armią znajdował się pod Łasinem. Część uczonych wiąże dokument ze zjazdem w Grudziądzu (T. Szulc, op. cit., s. 41), jednak wedle Długosza odbył się on na początku listopada, J. DŁugosz, 'Annales', 1445 $1461 \ldots$, s. 243.

${ }^{84}$ Niektórzy uczeni (T. Szulc, op. cit., s. 41; Lata wojny trzynastoletniej w „Rocznikach czyli Kronikach” inaczej „Historii polskiej” Jana Długosza (14541466), Komentarz krytyczny, oprac. S.M. KuczYŃsKi, I, Łódź 1964 s. 57) przyjmują, że to król wybrał nowych radców ze szlachty, jednak sam Długosz napisał, że nowi radcy zostali „wybrani ze szlachty” (ex communitate... electi: J. DŁugosz, 'Annales', 1445-1461..., s. 243) i przez szlachtę (nobiles per communitatem electos: J. DŁugosz, 'Annales', 1445-1461..., s. 247 i n.).

85 T. SzULC, op. cit., s. 41-43.

86 J. DŁugosz, 'Annales', 1445-1461..., s. 247 i n.; T. Szulc, op. cit, s. 46 i n. 
zapłacić pół grzywny (24 grosze). „Tę decyzję przyjęli prałaci, dostojnicy, szlachta i cała społeczność Wielkopolski. A dostojnicy ziem krakowskich $^{87}$ i Rusi, choć każdy sam wyrażał zgodę, jednak absolutnie nie mieli odwagi zobowiązać do tego społeczności, bo rzecz była nowa i trudna" 88 . Dla uzyskania zgody całej Małopolski, a głównie Rusi, na pobór postanowiono zwołać zjazd do Korczyna ${ }^{89}$. Wedle zachowanej uchwały piotrkowskiej w Korczynie miał odbyć się zjazd ziem krakowskiej, sandomierskiej, lubelskiej i ruskiej ${ }^{90}$. Wielkopolanie, którzy na podatki zgodzili się w Piotrkowie, mieli zebrać się w Kole (2 tygodnie po zjeździe Małopolan), by decydować o uwolnieniu szlachty dobrzyńskiej od podatku, czego nie uczyniono ${ }^{91}$. W Kole miały zjechać się ziemie wielkopolskie, sieradzka, łęczycka, kujawska, dobrzyńska $\mathrm{i}$ in. ${ }^{92}$. Warto zauważyć, że poza sejmem walnym w Piotrkowie wyraźnie występują tu sejmy prowincjonalne w Korczynie, dla całej Małopolski, i w Kole, dla całej Wielkopolski.

Na sejmie listopadowym w Piotrkowie w 1457 r. odroczono podjęcie definitywnej uchwały podatkowej do zjazdu w Kole. Nim ten się zebrał, król uzyskał zgodę Małopolan w Korczynie (podatek wiardunkowy), którą przyjęli też częściowo Wielkopolanie w Kole (6 gr. $)^{93}$. Zjazd w Korczynie Długosz określił jako zjazd ziem krakowskich i Rusi (terrarium Cracoviensium et Russiae tenuit convencionem). Według kronikarza byli tam też biskup włocławski i kanclerz Jan i wysłani przez Wielkopolskę wojewodowie: kaliski i łęczycki. Postanowiono nałożyć wiardunek na całe Królestwo, i postanowienie to przekazano na-

${ }^{87}$ Barones vero terrarum Cracoviensium. J. DŁugosz, 'Annales', 1445-1461..., s. 262.

\footnotetext{
88 J. DŁugosz, Roczniki, 1445-1461..., s. 295.

89 T. SzULC, op. cit, s. 49 i n.

90 J.W. BANDTKIE, op. cit, s. 294.

91 T. Szulc, op. cit, s. 49.

92 J.W. BANDTKIE, op. cit., s. 294.

93 T. Szulc, op. cit, s. 55.
} 
tychmiast do wykonania i poborcom powierzono ściąganie podatku ${ }^{94}$. Długosz nie znał uchwały z Koła ${ }^{95}$, w której jest inna stawka podatku niż przyjęta w Korczynie.

W maju 1458 r. na sejmie walnym w Piotrkowie powołano powszechną wyprawę całego Królestwa (pospolite ruszenie) ${ }^{96}$. Zachowała się uchwała ze Środy, w której wyliczono dokładnie kontyngenty z miast Wielkopolski i Kujaw ${ }^{97}$.

Też w Piotrkowie, w styczniu następnego roku, rozstrzygnięcie kwestii sposobu prowadzenia wojny odłożono na zjazdy ziemskie i prowincjonalne. Stało się tak, żeby społeczność szlachecką, która odmawiała służby wojskowej i pieniędzy, ,doprowadzić z powrotem do zdrowego sposobu myślenia"98. W zachowanej uchwale ze zjazdu ${ }^{99}$ jest mowa o sejmach prowincjonalnych i sejmikach ziemskich. Co do tych ostatnich, podano terminy zebrania się, przy czym najpierw miał się zebrać sejmik w Środzie, a potem w jednym terminie sejmy w Kole i Korczynie, następnie sejmiki ziem sieradzkiej, łęczyckiej, kujawskiej.

W maju roku 1459 zebrały się sejmy prowincjonalne. Wielkopolanie postanowili podjąć walkę z Krzyżakami, Małopolanie odmówili zajmowania się wojną, dopóki nie zostanie zreformowane państwo. Domagali się zwołania sejmu w Piotrkowie. Król odmówił. Następnie odbyły się zjazdy w ziemiach krakowskich (conventus particulares in terris Cracoviensibus) i na nich krakowianie trwali przy swych postulatach. Wtedy król postanowił zwołać sejm do Piotrkowa. Wielkopolanie wysłali pospolite ruszenie ${ }^{100}$.

94 J. DŁugosz, 'Annales', 1445-1461..., s. 293 i n.; TenżE, Roczniki, 1445-1461..., s. 330 .

95 J.W. BANDTKIE, op. cit., s. 304.

96 J. DŁugosz, 'Annales', 1445-1461..., s. 302; Tenże, Roczniki, 1445-1461..., s. 341 .

${ }^{97}$ Kodeks Dyplomatyczny Wielkiej Polski, wyd. E. RaczyŃSKi, Poznań 1840, nr 129.

98 J. DŁugosz, Roczniki, 1445-1461..., s. 357.

99 J.W. BANDTKIE, op. cit., s. 306.

100 J. DŁugosz, 'Annales', 1445-1461..., s. 367; Tenże, Roczniki, 1445-1461..., s. 326 . 
Na zwołanym we wrześniu 1459 r. sejmie walnym w Piotrkowie P1 $^{10}$ uchwalono podatek 6 gr., na który pierwotnie nie zgodzili się Małopolanie, dopóki nie odbyli zjazdu w Korczynie ${ }^{102}$. W źródłach brak wiadomości o odbytych wtedy sejmikach ${ }^{103}$. Pod koniec tegoż roku odbył się znowu sejm w Piotrkowie. Według Długosza uchwalono tam podatki ${ }^{104}$, zdaniem jednak Tadeusza Szulca doszło do zmian we wcześniejszych (niezrealizowanych) uchwałach podatkowych ${ }^{105}$.

We wrześniu 1461 r. w obozie pod Chojnicami zdecydowano pobrać podatki od całego wojska ${ }^{106}$. W grudniu tegoż roku w Korczynie odbył się sejm walny. Sądzono na nim sprawców zabójstwa Andrzeja Tęczyńskiego i nałożono podatek na miasta i ziemian ${ }^{107}$.

W styczniu 1463 roku w Piotrkowie postanowiono za zgodą wszystkich powszechną wyprawę do Prus ${ }^{108}$. W lipcu tegoż roku w Korczynie postanowiono odłożyć pospolite ruszenie i zwołać kolejny zjazd w Piotrkowie oraz ustanowiono podatek na opłacenie zaciężnych ${ }^{109}$. Zdaniem Szulca był to zjazd prowincjonalny małopolski, gdyż król

${ }^{101}$ Zob. W. FaŁkowsKi, Rok trzech sejmów, [w:] 'Aetas media, aetas moderna'. Studia ofiarowane prof. Henrykowi Samsonowiczowi w siedemdziesięciolecie urodzin, Warszawa 2000, s. 413 i n.

102 J. DŁugosz, 'Annales', 1445-1461..., s. 332; Tenże, Roczniki, 1445-1461..., s. 373.

103 T. SzuLc, op. cit., s. 60.

104 J. DŁugosz, 'Annales', 1445-1461..., s. 335; Tenże, Roczniki, 1445-1461..., s. 377.

105 T. SzuLc, op. cit., s. 61 i n.

106 J. Deugosz, 'Annales', 1445-1461..., s. 366 i n.; Tenże, Roczniki, 1445-1461..,, s. 412. T. SzULC, op. cit., s. 64 i n.

107 J. Deugosz, 'Annales', 1445-1461..., s. 374; Tenże, Roczniki, 1445-1461..., s. 421. T. SzulC, op. cit., s. 65 i n.

108 J. Deugosz, 'Annales seu Cronicae incliti regni Poloniae, Liber duodecimus'1462-1480, Cracoviae 2005, s. 57; TenżE, Roczniki czyli Kroniki sławnego Królestwa Polskiego, Księga 12 1462-1480, Warszawa 2006, s. 63.

109 J. DŁugosz, 'Annales', 1462-1480..., s. 64 i n.; Tenże, Roczniki, 1462-1480..., s. 71 . 
w grudniu był w Kole ${ }^{110}$. Pewne informacje, podane przez Długosza, mogą świadczyć o tym, że był to jednak zjazd ogólnopolski. Według kronikarza podatek ustanowiono jako powszechne wsparcie (universale subsidium) i miał on zastapić pospolite ruszenie uchwalone na sejmie w Piotrkowie w styczniu. Więc zjazd (określony jako conventio generalis) można by uznać na ogólnopolski - decyzje miały obowiązywać powszechnie, a nie jest możliwe, by sami Małopolanie nałożyli obowiązki ogólnopaństwowe. Poza tym zjazd wielkopolski był w grudniu, a w październiku miał odbyć się sejm walny w Piotrkowie. Byłaby to więc nietypowa sekwencja zdarzeń: najpierw sejm prowincjonalny małopolski (lipiec), potem sejm walny i później sejm wielkopolski (grudzień). Nie da się jej jednak wykluczyć.

W październiku 1463 r. na wspomnianym sejmie w Piotrkowie szlachta podolska zobowiązała się dobrowolnie z każdego łanu i osady kmiecej dać jednego wołu na wykupienie Kamieńca i naprawę zamku $^{111}$. Z 7 grudnia tego roku pochodzi dokument, w którym król dziękował panom i szlachcie brzeskiej za zgodę na podatek (bez określenia wysokości) i przyrzekał, że tę zgodę będzie traktował jako jednorazową i podatek nie stanie się trwały ${ }^{112}$. Dokument ten wystawiono w Kole, tradycyjnym miejscu obrad sejmu prowincjonalnego, jednak dotyczy tylko Kujaw. Koło leżało na terenie województwa kaliskiego, więc raczej nie obradował tam sejmik brzeski. Możliwe, że szlachta brzeska wyraziła zgodę wcześniej na sejmiku, a w Kole uzyskała tylko potwierdzenie wolności podatkowych od obecnego tam Kazimierza Jagiellończyka. Nie można też wykluczyć możliwości otrzymania podobnych dokumentów przez inne ziemie, jednak takowe się nie dochowały.

W kwietniu 1464 r. odbył się w obecności króla zjazd ziem krakowskiej, sandomierskiej i ruskiej, na którym odwołano pospolite rusze-

110 T. SzULC, op. cit., s. 71.

111 J. DŁugosz, 'Annales', 1462-1480..., s. 77; Tenże, Roczniki, 1462-1480..., s. 84 .

112 Dokumenty kujawskie i mazowieckie przeważnie z XIII w., zebrał i wyd. B. UlANowsKI, [w:] Archiwum Komisji Historycznej, IV, Kraków 1888, nr 102. 
nie. Długosz napisał, że ustanowiono i na cały kraj rozłożono pobór wiardunkowy ${ }^{113}$, jednak wobec obecności na zjeździe tylko Małopolan i odbytego niewiele później zjazdu kolskiego wydaje się to niemożliwe ${ }^{114}$. W czerwcu tegoż roku zjazd odbył się w Kole. Długosz napisał, że obecni byli panowie wielkopolscy i pierwotnie chciano urządzić wyprawę powszechną rycerstwa wielkopolskiego. Ponieważ Wielkopolanie nie chcieli stawać do broni bez Małopolan, ustanowiono podatek wiardunkowy z Wielkopolski ${ }^{115}$.

$\mathrm{W}$ połowie kwietnia $1465 \mathrm{r}$. we Lwowie zdecydowano o podatku. Obecni byli liczni panowie i szlachta ruska i podolska ${ }^{116}$. Miesiąc później w Korczynie obecni byli radcy ziem krakowskich i ruskiej ${ }^{117}$, biskup krakowski Jan, włocławski Jakub, czterech pełnomocnych radców (wymienionych imiennie) delegowanych z Wielkopolski. Uchwalono nowy wiardunek na prowadzenie wojny pruskiej i zdecydowano, by Wielkopolanie ruszyli zbrojnie oblegać Chojnice. Za to mieli zapłacił połowę poboru ${ }^{118}$.

W marcu 1466 r. w Piotrkowie postanowiono, by król udał się do Prus i na jego tam utrzymanie nałożono podatek. Zdaniem Długosza „Wszyscy zatwierdzili i przyjęli tę decyzję"119

W 1467 r. nie uchwalono podatku, jednak najpierw odmówiono go na sejmach prowincjonalnych (Korczyn, Środa - kwiecień), potem negatywnie sprawą zajmował się sejm walny w Piotrkowie, po czym znowu bez efektów radziły nad nim sejmy prowincjonalne (Koło, Korczyn).

113 J. DŁugosz, 'Annales', 1462-1480..., s. 82; Tenże, Roczniki, 1462-1480..., s. 89.

114 Tak też T. SzULC, op. cit., s. 74.

115 J. Deugosz, 'Annales', 1462-1480..., s. 83; Tenże, Roczniki, 1462-1480..., s. 90 .

116 J. DŁugosz, 'Annales', 1462-1480..., s. 107; TenżE, Roczniki, 1462-1480..., s. 117.

117 Consiliarii parcium Cracoviensium et Rusie.

118 J. DŁugosz, 'Annales', 1462-1480..., s. 107 i n.; Tenże, Roczniki, 1462-1480..., s. 118.

119 J. DŁugosz, 'Annales', 1462-1480..., s. 130; Tenże, Roczniki, 1462-1480..., s. 140 . 
Pomiędzy terminami zjazdów było ponad 2 tygodnie różnicy, by mógł przybyć król, którego poproszono o osobisty udział ${ }^{120}$.

Intensywne wysiłki w celu zorganizowania środków na wojnę podjęto w 1468 r. Najpierw odbył się pod koniec czerwca zjazd w Wiślicy, z osobistym udziałem króla. W Wiślicy zdecydowano, że należy przyjść królowi z pomoca, jednak ostateczną decyzję odłożono do Piotrkowa, „by nie wydawało się, że pośpiesznie bez rycerzy wielkopolskich wyrazili zgodę"121. Po zjeździe wiślickim ze wszystkich districtus wybrano po dwóch posłów, którzy mieli pełnomocnictwo do zezwolenia na stosowny, a umiarkowany podatek. Na początku lipca miał miejsce zjazd (sejmik?) w Środzie, choć nie wiemy, co było przedmiotem ob$\operatorname{rad}^{122}$. W połowie miesiąca posłowie zjechali się w Kole, gdzie w obradach uczestniczył król. Kazimierz Jagiellończyk ponownie był obecny na zjeździe kolskim 5 października. Kilka dni później rozpoczął się sejm w Piotrkowie i ponownie w Kole pod koniec listopada. W grudniu odbył się zjazd w Korczynie, na którym Małopolanie z przedstawicielami Wielkopolski zgodzili się w końcu na podatek ${ }^{123}$.

Warto zatrzymać się chwilę nad informacją o posłach wybranych po zjeździe wiślickim. W Wiślicy odbył się zjazd prowincjonalny, więc posłowie byli wybierani tylko $\mathrm{w}$ tej prowincji. Wyraz districtus najczęściej oznaczał okręg sądowy zwany powiatem, który nie był okręgiem administracyjnym. Terminy ,powiat” i jego łacińskiego odpowiednika „districtus” były wieloznaczne i później sejmiki ziemskie nazywano powiatowymi ${ }^{124}$. Jest więc całkiem możliwe, że termin ten został użyty w znaczeniu ziemi, bo czasem już w średniowieczu występował

120 T. SzULC, op. cit., s. 80 i n.

121 J. DŁugosz, 'Annales', 1462-1480..., s. 219; Tenże, Roczniki, 1462-1480..., s. 230.

122 A. GĄSIOROwSKI, Uchwaty piotrkowskie i nowokorczyńskie roku 1468, «CPH» 20.2/1968, s. 67.

123 J. Deugosz, 'Annales', 1462-1480..., s. 227; Tenże, Roczniki, 1462-1480..., s. $237 \mathrm{i} \mathrm{n.}$

124 J. Bardach, Powiat w Polsce późnośredniowiecznej, «CPH»19.2/1967, s. 142. 
zamiennie z terminem terra ${ }^{125}$. Mielibyśmy zatem do czynienia z reprezentacją antycypującą sposób wybierania ustalony pod koniec XV w.

14 X 1470 w Korczynie król uzyskał zgodę panów i szlachty ziem krakowskich (terrarum Cracoviensium) na wsparcie finansowe dla wojsk najemnych. Następnie udał się do Piotrkowa, gdzie prosił członków rady i rycerzy o wniesienie uchwalonej pomocy pieniężnej. Tam spotkał się z opozycją. Poza tym brak było rycerzy wielkopolskich, którzy celowo nie przybyli na wspomniany zjazd, ,jak też na inne zjazdy, które odbywały się przed walnym, aby przez swą nieobecność uchylić się od uchwalenia pomocy". Zjazd przeciagnął się do 30 dni. Po spełnieniu przez króla niektórych żądań (wydanie konfirmacji praw z pieczęcią majestatowa) postanowiono wiardunki ze wszystkich łanów Królestwa oraz inne podatki ${ }^{126}$. Dalej Długosz napisał, że w grudniu ,król udał się do Koła, gdzie odbywał się zjazd rycerzy (conventus militarum) wielkopolskich i tam nakłonił wahających się do zgody na podatek wiardunkowy"127.

W marcu 1472 roku w Piotrkowie, ,nie można było podjąć żadnej skutecznej decyzji z powodu niezgodności głosów (ob disparitatem votorum)". Decyzję w sprawie podatków odłożono do zjazdów prowincjonalnych (ad diaetas particulares), które miały się odbyć w Korczynie i Kole. Na sejmie małopolskim król uzyskał zgodę panów i rycerzy na wypłacenie w ciągu kilku dni po 1 wiardunku. Na to samo przystali panowie wielkopolscy na zjeździe w Kole. Także cały kler czterech diecezji udzielił znacznej pomocy ${ }^{128}$. Na jesieni tegoż roku w Korczynie odbył się zjazd ziem krakowskich (conventio

125 K. ORZEChOWSKI, 'Terra' $w$ terminologii polskich źródel do końca XIV wieku, «CPH» 35.2/1983, s. 41 i n.

126 J. DŁugosz, ‘Annales', 1462-1480..., s. 257 i n.; TenżE, Roczniki, 1462-1480..., s. $269-70$.

127 J. DŁugosz, 'Annales', 1462-1480..., s. 260; TenżE, Roczniki, 1462-1480..., S. 272 .

128 J. DŁugosz, 'Annales', 1462-1480..., s. 287; Tenże, Roczniki, 1462-1480..., s. 301 . 
terrarum Cracoviensium). Król uzyskał tam podatek 6 groszy z łanu ${ }^{129}$. Następnie udał się na zjazd do Piotrkowa. Tam na początku listopada przeznaczono dla króla Czech Władysława ,jako wsparcie w postaci 6 groszy z każdego łana od rycerzy, a od kleru diecezji gnieźnieńskiej, włocławskiej i poznańskiej król zażądał po wiardunku od grzywny, ale odpowiedź odłożono do prywatnych zjazdów (privati conventus)" "130. Nie jest jasne, czy zjazdy prywatne dotyczą zjazdów duchowieństwa czy sejmików. O tych ostatnich nie ma przekazów źródłowych. Poza tym Długosz nigdy nie użył takiej nazwy na oznaczenie sejmików. W innych źródłach mamy tylko informację o uchwałach kolskich dotyczących prawa sądowego z grudnia $1472^{131}$. Nie ma tam mowy o podatkach. Szulc ${ }^{132}$ przyjmuje za Pawińskim ${ }^{133}$, że śladem uchwał podatkowych ze zjazdów prowincjonalnych z końca roku jest nagłówek w Annales: Kazimirus Rex Polonie tributum Polonis indicit ${ }^{134}$. Jednak w najnowszym wydaniu zamiast Polonis jest Lithuanis $^{135}$, poza tym nagłówki nie pochodzą od Długosza, a są pracą szesnastowiecznego kopisty ${ }^{136}$.

Na przełomie lat 1473 i 1474 odbył król kilka zjazdów w Wiślicy i Opatowcu. Zmieniono miejsce obrad z powodu zarazy w Korczynie. Ustanowiono pobór po 6 groszy z łanu ${ }^{137}$. Nie wiemy, kto był obec-

129 J. DŁugosz, 'Annales', 1462-1480..., s. 293; Tenże, Roczniki, 1462-1480..., s. $307 \mathrm{in}$.

130 J. DŁugosz, 'Annales', 1462-1480..., s. 295; Tenże, Roczniki, 1462-1480..., s. 310 .

131 A. Pawiński, op. cit, Dodatki nr 156.

132 T. Szulc, op. cit., s. 97 i n.

133 A. PAWIŃSKI, op. cit, s. 139 przyp.5.

134 J. Deugosz, Historia Polonica, V, Cracoviae 1878, s. 578.

135 J. DŁugosz, 'Annales', 1462-1480..., s. 299.

136 W. Semkowicz-Zarembina, Powstanie i dzieje autografu 'Annalium' Jana Długosza, «Rozprawy Wydziału Historyczno- Filozoficznego PAU», Ser. II, 47.1/1952, s. 16 i n. Zob. też TeJże, Przedmowa do Roczniki czyli Kroniki sławnego Królestwa Polskiego: dzieło czcigodnego Jana Dtugosza..., Warszawa 1962, s. 11.

137 J. DŁugosz, ‘Annales', 1462-1480..., s. 322 i n.; TenżE, Roczniki, 1462-1480..., s. 337 . 
ny. Jaki był zakres terytorialny postanowień, wskazuje skierowanie mandatu do starostów krakowskiego, sandomierskiego, korczyńskiego, radomskiego i lubelskiego ${ }^{138}$ - wszystkich małopolskich oraz samo miejsce zjazdu. Można więc przyjąć, że podatki miały mieć charakter lokalny (prowincjonalny). Później, w czerwcu tego roku, na sejmie w Piotrkowie (conventio generalis Regni), król nakazał w całym Królestwie pospolite ruszenie na wyprawę przeciw Maciejowi Korwinowi ${ }^{139}$.

W listopadzie 1475 r. odbył się zjazd rady królewskiej w Sieradzu. Zjawiło się na nim niewielu radców, i tylko z Wielkopolski. Wielkopolanie zgodzili się na pobór 6 groszy z łanu, pod warunkiem, że członkowie rady ziem krakowskich i Rusi uchwalągo w takiej samej wysokości ${ }^{140}$. W sierpniu następnego roku na sejmie w Piotrkowie król zarządził pospolite ruszenie z Rusi na pomoc Stefanowi wołoskiemu ${ }^{141}$.

We wrześniu 1476 r. w Korczynie odbył się zjazd dostojników ziem krakowskich, szlachty i króla. Kazimierz Jagiellończyk uzyskał pobór po 4 grosze z łanu na obronę ziem ruskich ${ }^{142}$. Wielkopolanie obiecali zebrać podatki, jeśli wyrażą na nie zgodę Małopolanie, jednak nie dotrzymali obietnicy z powodu sporów ze swym starostą.

Pod koniec r. 1477 miał miejsce sejm prowincjonalny (diaeta, diaeta particularis) ziem krakowskich i ruskiej w Korczynie. Król bezskutecznie zabiegał o pobór. Naznaczono następny zjazd (diaeta) w Korczynie 1 marca $1478^{143}$. Uchwalono pobór. Z tekstu kronikarza nie wynika, czy zgodę na pobór dano na zjeździe w 1477 czy w 1478.

138 J.W. BANDTKIE, op. cit, s. 317.

139 J. DŁugosz, 'Annales', 1462-1480..., s. 334; Tenże, Roczniki, 1462-1480..., s. 348 i n.

${ }^{140}$ J. DŁugosz, 'Annales', 1462-1480..., s. 367 i n; Tenże, Roczniki, 1462-1480..., s. 383 i n.

141 J. DŁugosz, 'Annales', 1462-1480..., s. 382; Tenże, Roczniki, 1462-1480..., s. 397.

142 J. DŁugosz, 'Annales', 1462-1480..., s. 384; TenżE, Roczniki, 1462-1480..., s. 400 .

143 J. DŁugosz, 'Annales', 1462-1480..., s. 405 i n.; Tenże, Roczniki, 1462-1480..., s. 421. 
W styczniu 1478 r. zebrał się sejm walny w Piotrkowie. Wobec braku pieniędzy niektórzy doradcy radzili, by uchwalić pobór wiardunkowy od kmieci. Temu się wielu ze szlachty sprzeciwiło i rzecz odesłano na sejmy prowincjonalne (conventus particulares) ${ }^{144}$. Być może chodziło tam wspomniany wyżej sejm małopolski w Korczynie.

W maju 1478 na sejmie walnym w Piotrkowie król uzyskał zgodę na pobór wiardunkowy $\mathrm{z}$ całego Królestwa ${ }^{145}$. Prawdopodobnie zgodzili się Wielkopolanie, po wcześniejszej - w marcu - zgodzie Małopolan ${ }^{146}$.

$\mathrm{Na}$ początku następnego roku na sejmie w Piotrkowie na żądanie króla wszyscy prałaci i panowie polscy zgodzili się na akcyzę we wszystkich miastach ziem krakowskich i Rusi należących do Kościoła i rycerzy ${ }^{147}$. W lutym i marcu tego roku król był obecny w Kole. Tam i na innych sejmach partykularnych (diaetae particulariter habitae) uchwalono akcyzę we wszystkich miastach ${ }^{148}$. Długosz napisał, że w Łęczycy Wielkopolanie zgodzili się na wybieranie akcyzy w miastach ${ }^{149}$.

Po zakończeniu kroniki wraz ze śmiercią Jana Długosza nasze informacje stają się mniej dokładne. Wedle ustaleń Tadeusz Szulca w r. 1482 przyjęto podatek, jednak nie wiemy, gdzie i kiedy tak się stało ${ }^{150}$. Pod koniec 1484 r. król był obecny na sejmie w Piotrkowie, a następnie w początku r. 1485 udał się na sejmy prowincjonalne do Korczyna

144 J. DŁugosz, 'Annales', 1462-1480..., s. 407; TenżE, Roczniki, 1462-1480..., s. 422.

145 J. DŁugosz, 'Annales', 1462-1480..., s. 415; TenżE, Roczniki, 1462-1480..., s. 430 .

146 T. SzULC, op. cit., s. 110.

147 J. DŁugosz, 'Annales', 1462-1480..., s. 428 i n.; Tenże, Roczniki, 1462-1480..,, s. 443.

148 J. DŁugosz, 'Annales', 1462-1480..., s. 425; TenżE, Roczniki, 1462-1480..., s. 440 .

149 J. Deugosz, 'Annales', 1462-1480..., s. 428 i n.; Tenże, Roczniki, 1462-1480..., s. 443.

150 T. SzULC, op. cit, s. 118 i n. 
i Koła ${ }^{151}$. W tym czasie podjęto uchwały podatkowe, jednak nie wiemy, gdzie i kiedy to się stało ${ }^{152}$. Kwestiami podatkowymi zajmował się znowu sejm piotrkowski na przełomie 1487 i 1488 roku i po nim sejmy prowincjonalne w Korczynie i Kłodawie ${ }^{153}$. Z roku 1489 pochodzą informacje o nałożeniu podatków na miasta i zgodzie duchowieństwa na własne świadczenia. $Z$ reguły towarzyszyły one podatkom płaconym przez szlachtę. Jednak nie mamy o nich pewnych informacji ${ }^{154}$. Za lata podatkowe uznał Tadeusz Szulc także 1490 i 1493, nie znamy jednak znowu miejsca, trybu, dokładniejszego czasu przyjęcia podatków i ich wysokości ${ }^{155}$.

Z chwilą objęcia tronu przez Jana Olbrachta zmieniła się praktyka funkcjonowania sejmów i sejmików, co jest rzeczą doskonale znaną ${ }^{156}$. Zanikają sejmy prowincjonalne, przekształcając się w sejmiki generalne, czyli przedsejmowe zjazdy posłów i senatorów z jednej prowincji podejmowane w celu uzgodnienia stanowisk na sejm walny ${ }^{157}$. Po kilkudziesięciu latach współistnienia sejmów walnych i prowincjonalnych doszło do częściowego usunięcia różnic regionalnych, będących pozostałością epoki rozbicia dzielnicowego.

Jak widać, w praktyce sejmiki ziemskie po 1454 nie zajmowały się sprawami podatków czy pospolitego ruszenia. Nie mamy ani jednego

\footnotetext{
151 Tamże, s. 121-2, przyp. 7.

152 Tamże, s. 120-122.

153 Tamże, s. 123 i n.

154 Tamże, s. 126 i n.

155 Tamże, s. 128-132.
}

156 S. Grodziski, Pięćset lat sejmu polskiego. Rzut oka na stan badań, «Przegląd Sejmowy» 1.1/1993, s. 13 i n. Ze starszej literatury warto wskazać prace M. BoBRZYŃSKIEGO, Sejmy polskie za Olbrachta i Aleksandra, [w:] Tegoż, Szkice i studia historyczne, I, Kraków 1922, s. 184-257 i biografie królów F. PAPÉEGO, Jan Olbracht, Kraków 2006 i Aleksander Jagiellończyk, Kraków 2006. Z nowszej literatury trzeba wymienić artykuł J. BARDACHA, O stawaniu się sejmu polskiego we wspótczesnej historiografii, [w:] Parlamentaryzm w Polsce we wspótczesnej historiografii, pod red. J. BARDACHa przy współudz. W. SudNIK, Warszawa 1995, s. 9-28.

157 W. URuszczak, Sejm walny koronny w latach 1506-1540, Warszawa 1980 s. 124 in. 
pewnego przekazu źródłowego, na którego podstawie możemy jednoznacznie stwierdzić, że sejmik średzki lub sieradzki podejmował decyzje w omawianych sprawach. Co więcej, Długosz nie podał ani razu informacji o tym, że odmówiono podatku ze względu na nieodpowiednie forum (szczególnie w Piotrkowie).

Kwestie podatkowe były poruszane na sejmie walnym lub sejmach prowincjonalnych. Przypisywanie istotnej roli sejmikom ziemskim w tej epoce wynikać może z nieustalonej terminologii łacińskiej. Określeniem Conventio (lub conventus) generalis nazywano i sejm walny, i sejm prowincjonalny. Te ostatnie nazywane były także conventio (lub conventus) particularis, które to określenia stosowano czasem do sejmików ziemskich. Do nich jedynie stosowano nazwę conventio terrestrii ${ }^{158}$. Należy jednak odróżniać sejmiki ziemskie w ziemiach, sejmy prowincjonalne dla Wielkopolski i Małopolski oraz sejm walny Królestwa Polskiego. Sejmiki zjeżdżały się w miastach, które zostały wymienione w konstytucji 1496 r. ${ }^{159}$, np. sejmik województw poznańskiego i kaliskiego w Środzie Wielkopolskiej. Wielkopolski sejm prowincjonalny z reguły odbywał się w Kole, a sejm walny w Piotrkowie. Owe zjazdy różniły się bardziej obszarem geograficznym, z którego się zjeżdżano, niż składem osobowym ${ }^{160}$.

W Małopolsce spotykamy się z sejmami prowincjonalnymi dla województwa krakowskiego, sandomierskiego z ziemią lubelską i czasem Rusi. Odbywały się one z reguły w Korczynie. Dopiero w końcu XV w. spotykamy w źródłach ślady sejmików ziemskich krakowskich w Proszowicach, sandomierskich w Opatowie ${ }^{161}$.

Na podstawie zebranego materiału można wysnuć pewne prawidłowości dotyczące życia politycznego w Polsce w drugiej połowie XV w. Silne są jeszcze regionalizmy, choć możliwe, że świadomie były one

158 Sprawom terminologii łacińskiej zjazdów średniowiecznych poświęciłem dużo miejsca w swej pracy magisterskiej, której fragmenty zamierzam opublikować w najbliższym czasie w oddzielnym artykule.

159 Volumina Constitutionum, s. 77, art. 66.

${ }^{160}$ H. KarbownIK. Udziat przedstawicieli kapitut $w$ sejmach $i$ sejmikach dawnej Rzeczpospolitej (XV-XVIII wieku), «CPH» 22.2/1970, s. 170 i n.

161 A. PAwiński, op. cit., s. 42. 
rozgrywane przez monarchę, który czuł się silniejszy wobec reprezentacji prowincji niż wobec przedstawicieli całej Korony. Widać odmienne interesy kierujące panami małopolskimi i wielkopolskimi. Można zaobserwować pewnego rodzaju równorzędność sejmu walnego i zjazdów prowincjonalnych, gdyż sprawy nie załatwione na sejmie walnym przesyłano na sejmy prowincjonalne, albo odwrotnie. Stałe miejsca obrad świadczyć mogą o pewnej, ustalonej już tradycji funkcjonowania owych zjazdów. Ciekawa wydaje się współpraca sejmów obu prowincji, które wzajemnie obsyłały się posłami, dla wypracowania wspólnego stanowiska.

Niewątpliwie od połowy XV w. można odnotować zwiększoną aktywność sejmów walnych i prowincjonalnych. Jednak nie świadczy to o zwiększonej roli szlachty w Królestwie Polskim i nie daje podstaw do stwierdzenia istotnych zmian ustrojowych w państwie.

Sejmiki ziemskie rozwijały się w XV w., zwiększając zakres spraw poddawanych pod ich dyskusję. Jednak w znacznej mierze były to sprawy lokalne, jak doskonale to widać z prac Pawińskiego ${ }^{162}$, Rucińskiego ${ }^{163}$ i Włodarczyka ${ }^{164}$ i dla Rusi Chodynickiego ${ }^{165}$. Włodarczyk wyraźnie stwierdził w odniesieniu do województwa łęczyckiego, że nie mamy żadnych przekazów źródłowych, które dotyczyły stanowiska tej ziemi wobec zagadnień politycznych ogólnopaństwowych. Może wynikać to ze specyfiki źródeł, którymi są głównie księgi sądowe ${ }^{166}$.

Nie jest jasna rola szlachty przybyłej na sejmiki w drugiej połowie XV wieku. Pawiński utożsamiał sejmiki ze szlachtą ${ }^{167}$. Natomiast Włodarczyk udział szlachty w sejmikach sprowadzał do biernego audytorium decyzji podejmowanych przez panów ${ }^{168}$. Według ustaleń

162 A. PAwińsKi, op. cit.

${ }^{163}$ H. RuciŃSKI, op. cit, szczeg. s. 39.

164 J. WŁodarczyK, Sejmiki łęczyckie do poczatku XVI wieku, «CPH» 12.2/1960, s. 19, 21 oraz Tenże, Sejmiki łęczyckie, Łódź 1973.

165 H. Chodynicki, Sejmiki ziem ruskich w wieku XV, Lwów 1906.

166 J. WŁodarczyK, Sejmiki łęczyckie do poczatku XVI wieku..., s. 44.

167 A. PAWIŃSKI, op. cit, s. 105 (sejmiki czyli szlachta).

168 J. WŁodarczYK, Sejmiki łęczyckie do poczatku XVI wieku..., s. 32. 
Wacława Uruszczaka, szlachta na sejmikach zaczęła się emancypować spod wpływów możnowładztwa (zasiadającego w senacie) w latach 20-tych XVI w. ${ }^{169}$

Wzrost znaczenia sejmików ziemskich związany był z utrwaleniem funkcjonowania posłów ziemskich na sejmie walnym (koniec XV w.). Wcześniej sejmiki miały charakter ściśle lokalny, w znacznej mierze sądowy. Tak widać to w źródłach, którymi są głównie księgi sądowe. W księgach sądowych łęczyckich można wyróżnić dwa nurty działalności sejmiku: lokalne prawodawstwo w zakresie prawa sądowego oraz sprawowanie sądownictwa przez sejmik. Szeroki zakres ustawodawstwa w łęczyckim spowodowany był tym, że nie obowiązywały tam statuty Kazimierza Wielkiego ${ }^{170}$. Warto pamiętać o tym, że istotnym problemem jest brak źródeł i terytorialnie nierównomierne ich rozmieszczenie (dobrze zachowane źródła łęczyckie nie muszą przesądzać o wyjątkowości sejmiku łęczyckiego).

Niewiele miejsca poświęcił przywilejom nieszawskim w swej Kronice Jan Długosz. Napisał „rycerze wielkopolscy zapomniawszy o dawnej karności rycerskiej, posłuszeństwie i czci wobec królów i Rzeczypospolitej, którą okazywali ich ojcowie... zbuntowawszy domagali się zatwierdzenia praw Królestwa i nadania nowych, bo inaczej nie pójdą ...do walki. A kiedy król, zatwierdziwszy dawne prawa, uspokoił ich zuchwałe żądania..." ${ }^{171}$. Wedle kronikarza w Nieszawie król „,zatwierdził prawa Królestwa nadane przez swoich poprzedników i dodał od nowa pewne wolności i przywileje"172. Wcześniejszym przywilejom kanonik krakowski poświęcił dużo więcej miejsca. W swym

169 W. UruszczaK, Sejm walny..., s. 108 i n.

170 J. WŁodarczyK, Sejmiki łęczyckie do poczatku XVI wieku..., s. 33.

171 J. DŁugosz, 'Annales', 1462-1480..., s. 211; Tenże, Roczniki, 1462-1480..., s. $238 \mathrm{i} \mathrm{n.}$

172 J. DŁugosz, 'Annales', 1462-1480..., s. 222; TenżE, Roczniki, 1462-1480..., s. 251. 
dziele w całości przytoczył przywilej budziński ${ }^{173}$ i jedlneński ${ }^{174}$ i obszernie omówił (choć błędnie ${ }^{175}$ ) zasadniczą treść przywileju koszyckiego ${ }^{176}$. Długosz miał rację, odmawiając przywilejom nieszawskim przełomowego znaczenia.

Dalsze szczegółowe badania, zwłaszcza nieopublikowanych jeszcze źródeł - głównie ksiąg sądowych, mogą zweryfikować tezę postawioną przez autora. Wydaje się jednak mało prawdopodobne ${ }^{177}$, by można było znaleźć tam przekazy wykazujące wyłączną kompetencję sejmików w zakresie nakładania podatków i stanowienia praw. Także dlatego, że informacje podane przez Długosza są obfite i w większości rzetelne. Warto jednak zauważyć, że tradycyjne zapatrywania literatury na znaczenie sejmików ziemskich w drugiej połowie XV wieku opierały się tylko na tekście przywileju nieszawskiego i ignorowały przekaz kronikarza.

\section{INNE PRZYKŁADY NIEOBOWIAZZYWANIA NORM PRZYWILEJÓW}

Innym przykładem na to, że normy ustanowione w przywileju nieszawskim nie obowiązywały, jest obowiązek osobistego sądzenia przez urzędników (poza wojewodą i starostą - ci w wyjątkowych sytuacjach mogli wyznaczyć zastępcę) $)^{178}$. Po gruntownych badaniach praktyki wielkopolskiej Antoni Gąsiorowski uznał, że dopiero początek XVI w. przyniósł zasadę osobistego zasiadania sędziego i podsędka na rokach

173 J. DŁugosz, Annales seu Cronicae incliti regni Poloniae, Liber nonus, Varsaviae 1978, s. 274-276.

174 J. Deugosz, Annales seu Cronicae incliti regni Poloniae, Liber undecimus 14131413, Varsaviae 2000, s. 276-282.

175 J.S. Matuszewski, Przywileje i polityka podatkowa Ludwika Wegierskiego w Polsce, Łódź 1983, s. 120-129.

176 J. DŁugosz, Roczniki czyli Kroniki sławnego Królestwa Polskiego, Księga 10 1370-1405, Warszawa 1981, s. 48-50.

177 Tym bardziej, że ziemskie księgi sądowe były podstawowym źródłem pracy A. Pawińskiego, op. cit.

178 M. BobrzyŃski, O ustawodawstwie nieszawskiem..., s. 55, art. 14 przywileju wielkopolskiego. 
sądowych $^{179}$. Również na przełomie XV i XVI w. wykształciła się zasada stałego zasiadania pisarza ziemskiego w sądzie ${ }^{180}$. Co ciekawe, zajmując się przepisami przywileju nieszawskiego o osobistym zasiadaniu w sądzie, Stanisław Kutrzeba już w 1902 r. zauważył: „Jak tyle innych przepisów statutów nieszawskich, tak i te ... nie weszły wcale w życie" 181 . Ten sam uczony zauważył też, że częstotliwość odbywania posiedzeń sądu ziemskiego, która wedle przywilejów nieszawskich miała wynosić raz na 4 tygodnie, dopiero później weszła w życie ${ }^{182}$.

Nie tylko przywileje nieszawskie zawierały normy, które pozostały wyłącznie na papierze. Już dawno Władysław Abraham zauważył, że podobnie było w XV w. z instytucją justycjariuszy, których urząd Władysław Jagiełło $\mathrm{w}$ swych przywilejach zobowiązał się zlikwidować, a pomimo to działali później ${ }^{183}$.

Innym przykładem względności obowiązywania przepisów przywilejowych jest sprawa Jana Strasza, który wbrew postanowieniom przywileju jedleńskiego był więziony na rozkaz Władysława Jagiełły mimo wyroku uniewinniającego, który wydał sąd ${ }^{184}$.

Henryk Grajewski zwrócił uwagę na często występujące potwierdzanie dawnych praw nowymi ustawami (tzw. reasumowanie ustawy),

179 A. GąsIorowski, Urzędnicy zarządu lokalnego w późnośredniowiecznej Wielkopolsce, Poznań 1970, s. 52-53.

180 Tamże, s. 55-56.

181 S. KutrzeBA, Sady ziemskie i grodzkie w wiekach średnich, IX, X: Województwa poznańskie i kaliskie, XI: Ziemia wschowska, Kraków 1902, s. 16.

182 S. Kutrzeba, Historia ustroju Polski w zarysie, I: Korona, Lwów-Warszawa 1925, s. 267.

${ }^{183}$ W. Abraham, O justyciariuszach $w$ Polsce XIV i XV wieku, «Rozprawy i Sprawozdania z Posiedzeń Wydziału Historyczno-Filozoficznego Akademii Umiejętności»19/1887, s. 55. Też M. Handelsman, Przywilej piotrkowski 1388 r. Szkic historyczno-prawny, [w:] Średniowiecze polskie i powszechne. Wybór pism, Warszawa 1966, s. 26 i n.

184 Sprawę tę omawiam w artykule 'Neminem captivabimus nisi iure victum', [w:] Łacińskie paremie $w$ europejskiej kulturze prawnej i orzecznictwie sadów polskich, red.: W. WoŁodkiewicz, J. KRZYżóweK, Warszawa 2001, s. 222-226. 
mające na celu ich rzeczywiste wykonanie ${ }^{185}$. Powtarzanie przepisów raz wydanych wynikało więc z natury rzeczy i było nieuniknione ${ }^{186}$. Wiadomo, że za czasów Zygmunta I istniała doktryna, wedle której prawa i przywileje nie obowiązywały w sposób absolutny, a król mógł w przypadku konieczności uchylić obowiązywanie prawa ${ }^{187}$.

\section{ZAKOŃCZENIE}

W dawniejszej historiografii często posługiwano się terminami intuicyjnie, nie próbując ich zdefiniować czy doprecyzować. Prowadziło to do wielu nieporozumień, zwłaszcza przy terminach używanych od starożytności, które zmieniały swą treść, czego nie zauważano (państwo, władza, konstytucja). Często przy pobieżnym badaniu instytucji doszukiwano się jej ,starożytnych" korzeni w instytucjach o podobnej nazwie. Podobieństwo umożliwiało też znajdowanie starej genezy instytucji współczesnych, lub powstałych niedawno, przy czym nie zwracano uwagi na ich specyfikę (np., konstytucjonalizm, prawa człowieka). Jedną z form takiego przedstawiania historii są konkursy typu „pierwszy”, „pierwsza” (konstytucja, ministerstwo edukacji, ustawa gwarantująca swobodę religijna, itp.). Trywializowanie pojęć zaciera różnice, osłabia znaczenie przełomów. Tak było w przypadku sejmu, którego genezę wywodzono z wieców, odbywanych jeszcze w czasach plemiennych. Dawało to asumpt niektórym badaczom (jak Lelewel) do wniosku o gminowładztwie Słowian, innym zaś o anarchicznym charakterze Polaków, którzy od początku ograniczali tylko władzę państwową by oddawać się prywacie. Trzeba głębiej wnikać w procesy

${ }^{185}$ H. GrajewSKI, Granice czasowe mocy obowiazujacej norm dawnego prawa polskiego, Łódź 1970, s.19 i n.

${ }^{186}$ M. BobrzyŃsKI, Sejmy polskie, s.187; Ten, O ustawodawstwie nieszawskim, s.126; S. Roman, Geneza statutów Kazimierza Wielkiego, Kraków 1961, s. 151; J. Matuszewski, Geneza statutów Kazimierza Wielkiego, «CPH» 14.2/1962, s. 212.

187 W. UruszczaK, 'Species privilegium sunt due, unum generale, alius speciale'. Przywileje w dawnej Polsce, «Studia z Dziejów Państwa i Prawa Polskiego» 11/2008, s. 27-27. Autor powołał się tu wprost na pisma powstałe w kancelarii królewskiej. 
społeczne, jeśli chcemy budować obraz przeszłości opisujący ją, a nie teraźniejszość.

Nieporozumienie z przywilejem nieszawskim o sejmikach wyniknęło w znacznej mierze nie z braku dostępnych źródeł, ale z nadmiernego przywiązania do metody dogmatycznej, opierającej się tylko na tekstach prawnych. Bez badania funkcjonowania instytucji w życiu społecznym nie jesteśmy w stanie nic o nich powiedzieć prawdziwego.

\author{
Between Estate Monarchy and Democracy of the \\ Gentry. The Importance of the Privileges of Nieszawa \\ for the Periodization of History of Poland
}

\title{
Summary
}

In his article the author deals with the issue of periodization of the history of the Polish political system. In particular the author concentrates on one of the privileges issued by the king Casimir IV Jagiellon in 1454 in Nieszawa. According to this privilege the king should not legislate or summon the nobility to war without a local diet assembly (sejmik). In the opinion of some authors who deal with the issue it was the time (the year 1454) when the importance of local diets was raised and the position of the nobility within the structure of the authorities of the Kingdom of Poland was settled. The author emphasises that the privilege concerned only Wielkopolska and analyses the information about militia calling out in the second half of the $15^{\text {th }}$ century. On the basis of the sources gathered, the author makes the conclusion that the article mentioned had not been put in force as it was plenary or provincial diets that made decisions about militia calling or taxes, and not local diets. Therefore, in the author's opinion the date 1454 does not make any decisive moment for the history of the Polish political system. 